\title{
CARDIOVASCULAR RISK IN PATIENTS WITH SUBCLINICAL HYPOTHYROIDISM
}

\section{Medicine \\ Dr. Anil Kumar Mehta*}

M.D. (Medicine), DTM \& H, Associate Professor, Department ofMedicine, Darbhanga Medical College and Hospital, Laheriasarai, Bihar. *Corresponding Author
Dr. Debarshi Jana

Young Scientist (DST) Institute of Post-Graduate Medical Education and Research, A.J.C. Bose Road, Kolkata-700020, West Bengal, India.

\section{ABSTRACT}

Thyroid hormone regulate every organ system in our body. Metabolic parameters, including lipoprotein metabolism and cardiovascular risk factors like obesity, glucose intolerance or type 2 diabetes, dyslipidemia and hypertension are all influenced by serum TSH level in our body. Several reports have demonstrated a positive correlation between TSH levels and cardiovascular risk factors. C-reactive proteins is one of the markers of inflammation and also considered to be the predictor of cardiovascular disease and may be helpful in the assessment of future development of cardiovascular abnormalities in subclinical hypothyroidism.

Methods: Recently diagnosed 71 subclinical hypothyroidism patients were enrolled in the study and compared with 63 healthy individuals. Patients were divided into two groups on the basis of thyroid stimulating hormone (TSH) concentration. Thyroid profile (TSH, free thyroxine, triiodothyroinine) and C-reactive protein were estimated by enzyme-linked immunosorbent assay. Total cholesterol (TC), triglycerides (TG), and high-density lipoprotein-cholesterol were estimated in the study population by a spectrophotometric method, and low-density lipoproteincholesterol (LDL-C) was measured by the Friedewald formula.

Results and Conclusion: Altered lipid profile, as well as higher concentrations of C-reactive protein, was observed in subclinical hypothyroidism patients as compared to controls. Higher concentration of TC, TG, and LDL was observed in subclinical hypothyroidism patients while the concentration of high-density lipoprotein was lower in patients with subclinical hypothyroidism. The elevated concentration of $\mathrm{C}$-reactive protein was also observed in the patient group. Patients having TSH $>10 \mu \mathrm{IU} / \mathrm{ml}$ have a higher risk of developing cardiovascular disease compared to patients having TSH $<10 \mu \mathrm{IU} / \mathrm{ml}$ and increasing concentration of C-reactive protein along with LDL-C may to cardiovascular abnormality.

\section{KEYWORDS}

Subclinical hypothyroidism, C-reactive protein, Dyslipidemia, Cardiovascular risk.

\section{INTRODUCTION}

Subclinical hypothyroidism $(\mathrm{SCH})$ is a common endocrine disorder presented by mildly elevated thyroid stimulating hormone (TSH) above the reference range along with a normal concentration of free thyroxine (FT4) and triiodothyronine (T3). It is an oscillated state between euthyroidism to hypothyroidism as it may lead to overt hypothyroidism. Thyroid hormones are known to play a significant role in cardiac hemodynamic because the deficient or excessive concentration of thyroid hormones may develop cardiac abnormalities. It is well-established that overt hypothyroidism is associated with cardiovascular symptoms through biochemical analysis. Dyslipidemia is a prominent feature of hypothyroidism established by various evidences, but not for the $\mathrm{SCH}$ due to inconsistent findings over the years.

The diversity of the result has raised the question that whether SCH is characterized by cardiovascular symptoms or not. C-reactive protein (CRP), an acute-phase reactant, is an effective and stable tool for the assessment of cardiovascular risk. It is an important marker of various inflammatory disorders like rheumatoid arthritis, myocardial infarction and various others etc. CRP is known to play an important role in the progression of atherosclerosis, a cardiovascular disease caused by the altered mechanism of low-density lipoprotein cholesterol (LDL-C). Therefore, the main objective of this study is an assessment of the role of CRP in SCH patients.

\section{MATERIALAND METHODS}

This cross-sectional study was carried out in Department of Medicine, Darbhanga Medical College and Hospital, Laheriasarai, Bihar. Total 71 recently diagnosed SCH patients were enrolled for the study, in which 44 patients were having TSH 6.16- $10 \mu \mathrm{IU} / \mathrm{ml}$ and rest 27 patients were having TSH $>10 \mu \mathrm{IU} / \mathrm{ml}$ termed as Cases-I and Cases-II respectively, compared with 63 healthy individuals as controls. People with a previous history or family history of thyroid diseases, taking thyroid medication, cardiovascular disease, smoking, menopausal women, pregnancy, inflammation, diabetes, hypertension, or alcoholics were excluded from this study. Age group criteria were kept from 21 to 45 years for the study population.

Body mass index (BMI) was calculated by means of height and weight of an individual. The weight of a person is divided by the square of the height. The weight and height of an individual were measured in kilogram $(\mathrm{kg})$ and meter $(\mathrm{m})$, respectively. The person having BMI
$18.5 \mathrm{~kg} / \mathrm{m}^{2}$ to $24.99 \mathrm{~kg} / \mathrm{m}^{2}$ was considered a normal BMI. Thyroid profile (TSH, FT4 and T3) of SCH patients, as well as controls, was measured by enzyme-linked immunosorbent assay (ELISA). Patients with a concentration of $\mathrm{TSH}>6.2 \mu \mathrm{IU} / \mathrm{ml}$ along with a normal concentration of FT4 and T3 was considered to have SCH. ELISA kits was used for the investigation of thyroid profile estimation.

Total cholesterol (TC), triglycerides (TG), high-density lipoprotein cholesterol (HDL-C), and LDL-C were measured in the study group. $\mathrm{TC}, \mathrm{TG}$, and HDL-C were investigated by means of glucose oxidase (CHOD)/peroxidase (POD) method, GPO-PAP method and CHODPOD/phosphotungstate method, respectively.

\section{STATISTICALANALYSIS}

All the variables (age, BMI, TSH, FT4, T3, lipid profile, and CRP) were expressed in mean \pm standard deviation (SD). One-way ANOVA was used for the differentiation of all the parameters between the various groups (Control group, Cases-I and Cases-II). A $p<0.05$ was considered statistically significant. IBM SPSS version 20 (Statistical package for social sciences) was used for the statistical analysis.

\section{RESULT}

This study shows a statistical difference among the various groups regarding the different variables. The age of all the participants was not significantly different statistically. Thyroid profile (TSH and T3) was significantly different among the groups except the FT4. BMI was significantly different among the groups and was highest in Cases-II and lowest in control groups (Table 1).

Lipid profile was significantly different among the groups. TC, TG, and LDL-C were higher in SCH groups compared to control group and highest in Cases-II. HDL-C was significantly different among the groups. The lowest concentration of HDL-C was observed in the second group of SCH patients. The concentration was also lower in Cases-I comparing to control group. The level of CRP was significantly different among the groups as its level was comparatively increasing in each group, from Cases-I to the Cases-II (Table 2).

Table 1 : Baseline characteristics among the various groups $\stackrel{\ddagger}{\sharp}$

\begin{tabular}{|c|l|c|c|c|c|}
\hline $\begin{array}{c}\text { Sl. } \\
\text { No. }\end{array}$ & Parameters & $\begin{array}{c}\text { Control } \\
\mathbf{( 0 . 3 9 - 6 . 1 6} \\
\mathbf{m I U} / \mathbf{m l})\end{array}$ & $\begin{array}{c}\text { Case I } \\
\mathbf{( 6 . 1 6 - 1 0} \\
\mathbf{m I U} / \mathbf{m l})\end{array}$ & $\begin{array}{c}\text { Case II } \\
\mathbf{( > \mathbf { 1 0 . 0 }} \\
\mathbf{m I U} / \mathbf{m l})\end{array}$ & p-value \\
\hline 1 & Age (years) & $35.46 \pm 3.77$ & $35.75 \pm 3.71$ & $36.25 \pm 2.96$ & 0.628 \\
\hline
\end{tabular}


All the variables were expressed as mean \pm SD. $₫$ By analysis of variance, SD: Standard deviation, BMI: Body mass index, TSH: Thyroid stimulating hormone, FT4: Free thyroxine, T3: Triiodothyroinine

Table 2 :Lipid profile and CRP among the various groups:

\begin{tabular}{|c|c|c|c|c|c|}
\hline 2 & BMI $\left(\mathrm{kg} / \mathrm{m}^{2}\right)$ & $22.68 \pm 1.82$ & $26.4 \pm 2.13$ & $29.64 \pm 3.83$ & $<0.01$ \\
\hline 3 & TSH $(\mathrm{mIU} / \mathrm{ml})$ & $2.75 \pm 0.78$ & $8.20 \pm 0.82$ & $14.86 \pm 2.95$ & $<0.01$ \\
\hline 4 & FT4 $(\mathrm{ng} / \mathrm{dl})$ & $1.15 \pm 0.20$ & $1.15 \pm 0.24$ & $1.25 \pm 0.30$ & 0.196 \\
\hline 5 & T3 $(\mathrm{ng} / \mathrm{dl})$ & $1.08 \pm 0.28$ & $0.95 \pm 0.18$ & $0.93 \pm 0.15$ & $<0.01$ \\
\hline
\end{tabular}

All the variables were expressed as mean $\pm \mathrm{SD}$, $\ddagger$ By analysis of variance, CPR: C-reactive protein, TC: Total cholesterol, TG: Triglycerides, HDL: High-density lipoprotein, LDL: Low-density lipoprote

\section{DISCUSSION}

This study shows that $\mathrm{SCH}$ patients are characterized by increased BMI, lipid profiles, and CRP level. Rotterdam Study specified that subclinical hypothyroidism is a strong predictor of myocardial infarction and risk of atherosclerosis. Elevated TSH is found to be associated with increased BMI in SCH patients. Srideviet al. supported our study by signifying altered concentration of lipid profile as characterized by significantly increased level of TC, a higher concentration of TG and elevated LDL-C. Similar to this study Erdemet al. observed that the concentration of HDL-C was significantly lower in $\mathrm{SCH}$ patients compared to controls.Study ofKvetnyet al.also support this study that $\mathrm{SCH}$ might be a risk factor for the development of cardiovascular diseases due to increased level of TG and CRP. CRP, a plasma protein, predominantly synthesized in liver, emerged as an additional cardiovascular risk factor was found to be significantly higher in the SCH group compared to control group. CRP has been reported to bind to oxidized LDL and actively participates in atherogenesis by direct influence on complement system, vascular cell activation, lipid accumulation and thrombosis. The level of CRP was significantly higher in $\mathrm{SCH}$ patients promising the approach for further development of cardiac risk, supported by Gaoet al. study. Gupta et al. also observed the increased concentration of inflammatory markers in SCH patients. While contrary to it other studies defined that $\mathrm{SCH}$ has no relation with dyslipidemia. Luboshitzkyet al. described that CRP does not play any role to contribute to the increased risk of cardiovascular disease in $\mathrm{SCH}$ patients. Toruneret al. described that $\mathrm{SCH}$ is characterized by dyslipidemia, but this association does not depend on the range of $\mathrm{TSH}$. This study proposed that $\mathrm{SCH}$ patients having $\mathrm{TSH}>10 \mu \mathrm{IU} / \mathrm{ml}$ have a higher risk of future development of cardiac abnormalities matched with Hernandez-Mijares andMarwaha study. In addition to this patients having $\mathrm{SCH}$ with $\mathrm{TSH}<10 \mu \mathrm{IU} / \mathrm{ml}$ also showed some indication of altered lipid fractions, comparing to control group supported by Regmi study.

\section{CONCLUSION}

The outcome of this study specifies that $\mathrm{SCH}$ patients are characterized by increased BMI, dyslipidemia, and a higher concentration of CRP. This significant increase in CRP level might be the cause of development of cardiac symptoms in the coming future. Cardiovascular abnormalities can be developed in the later stage of disease. Although there are remarkable changes in different variables in $\mathrm{SCH}$ patients having $\mathrm{TSH}>10 \mu \mathrm{IU} / \mathrm{ml}$, Patients with $\mathrm{SCH}$ in which TSH range was $<10 \mu \mathrm{IU} / \mathrm{ml}$ also has some alteration in different variables compared to normal healthy adults. Increased BMI, altered lipid fractions and abnormal CRP might be helpful in the early detection to diagnose cardiovascular risk in $\mathrm{SCH}$ patients. The sample size of this study was small, so the further studies with larger number of patients will be helpful to establish the fact.

\section{REFERENCES}

Abbas JM, Chakraborty J, Akanji AO, Doi SA. Hypothyroidism results in small dense LDL independent of IRS traits and hypertriglyceridemia. Endocr J 2008:55(2):381-9. Calabrò P, Golia E, Yeh ET. Role of C-reactive protein in acute myocardial infarction and stroke: Possible therapeutic approaches. Curr Pharm Biotechnol 2012;13(1):4-16. and stroke: Possible therapeutic approaches. Curr Pharm Biotechnol 2012;13(1):4-16.
Chang MK, Binder CJ, Torzewski M, Witztum JL. C-reactive protein binds to both oxidized LDL and apoptotic cells through recognition of a common ligand: Phosphorylcholine of oxidized phospholipids. ProcNatlAcadSci U S A2002;99:13043-8.

4. Christ-Crain M, Meier C, Guglielmetti M, Huber PR, Riesen W, Staub JJ, et al. Elevated C-reactive protein and homocysteine values: Cardiovascular risk factors in hypothyroidism? A cross-sectional and a double-blind, placebo-controlled trial. Atherosclerosis 2003;166(2):379-86

5. Erdem TY, Ercan M, Ugurlu S, Balci H, Acbay O, Gundogdu S. Plasma viscosity, an early cardiovascular risk factor in women with subclinical hypothyroidism. early cardiovascular risk factor in wome
ClinHemorheolMicrocirc 2008;38(4):219-25.

6. Erhardt JG, Estes JE, Pfeiffer CM, Biesalski HK, Craft NE. Combined measurement of ferritin, soluble transferrin receptor, retinol binding protein, and C-reactive protein by an inexpensive, sensitive, and simple sandwich enzyme-linked immunosorbent assay technique. J Nutr 2004;134(11):3127-32.

7. Fiarresga AJ, Feliciano J, Fernandes R, Martins A, Pelicano N, Timóteo AT, et al. Relationship between coronary disease and subclinical hypothyroidism: An angiographic study. Rev Port Cardiol 2009;28:535-43

8. Gan SD, Patel KR. Enzyme immunoassay and enzyme-linked immunosorbent assay. Invest Dermatol 2013;133(9):e12.

9. Gao CX, Yang B, Guo Q, Wei LH, Tian LM. High thyroid-stimulating hormone level is associated with the risk of developing atherosclerosis in subclinical hypothyroidism. HormMetab Res 2015;47(3):220-4.

10. Garrow JS, Webster J. Quetelet's index (W/H2) as a measure of fatness. Int J Obes $1985 ; 9(2): 147-53$

11. Gupta G, Sharma P, Kumar P, Itagappa M. Study on subclinical hypothyroidism and its association with various inflammatory markers. J ClinDiagn Res 2015;9(11):BC04-6.

12. Hak AE, Pols HA, Visser TJ, Drexhage HA, Hofman A, Witteman JC. Subclinical hypothyroidism is an independent risk factor for atherosclerosis and myocardia infarction in elderly women: The Rotterdam Study. Ann Intern Med 2000;132(4):270-8.

13. Hernández-Mijares A, Jover A, Bellod L, Bañuls C, Solá E, Veses S, et al. Relation between lipoprotein subfractions and TSH levels in the cardiovascular risk among women with subclinical hypothyroidism. ClinEndocrinol (Oxf) 2013;78(5):777-82.

14. Hueston WJ, King DE, Geesey ME. Serum biomarkers for cardiovascular inflammation in subclinical hypothyroidism. ClinEndocrinol (Oxf) 2005;63(5):582-7.

15. Kvetny J, Heldgaard PE, Bladbjerg EM, Gram J. Subclinical hypothyroidism is associated with a low-grade inflammation, increased triglyceride levels and predicts cardiovascular disease in males below 50 years. ClinEndocrinol (Oxf) 2004;61(12):232-8

16. Luboshitzky R, Herer P. Cardiovascular risk factors in middle-aged women with subclinical hypothyroidism. NeuroEndocrinolLett 2004;25(4):262-6.

17. Marwaha RK, Tandon N, Garg MK, Kanwar R, Sastry A, Narang A, et al. Dyslipidemia in subclinical hypothyroidism in an Indian population. ClinBiochem 2011;44(14 15):1214-7

18. Otterness IG. The value of C-reactive protein measurement in rheumatoid arthritis. Semin Arthritis Rheum 1994;24(2):91-104.

19. Pearce EN. Hypothyroidism and dyslipidemia: Modern concepts and approaches. CurrCardiol Rep 2004;6(6):451-6.

20. Regmi A, Shah B, Rai BR, Pandeya A. Serum lipid profile in patients with thyroid disorders in central Nepal. Nepal Med Coll J 2010;12(4):253-6

21. Ridker PM. Cardiology Patient Page. C-reactive protein: A simple test to help predict risk of heart attack and stroke. Circulation 2003;108(12):e81-5.

22. Rifai N, Warnick GR, Remaley AT. Lipids, lipoproteins, apolipoproteins, and other cardiovascular risk factors. In: Burtis CA, Ashwood ER, Bruns DE, editors. Teitz Fundamentals of Clinical Chemistry. Pennsylvania: Saunders An Imprint of Elsevier Inc.; 2010. p. 422-4.

23. Shekhar R, Chowdary NV, Das MC, Vidya D, Prabodh S. Prevalence of subclinical hypothyroidism in coastal Andhra Pradesh. Biomed Res 2011;22(4):471-4

24. Singh SK, Suresh MV, Voleti B, Agrawal A. The connection between C-reactive protein and atherosclerosis. Ann Med 2008;40(2):110-20.

25. Singh U, Dasu MR, Yancey PG, Afify A, Devaraj S, Jialal I. Human C-reactive protein promotes oxidized low density lipoprotein uptake and matrix metalloproteinase-9 release in Wistar rats. J Lipid Res 2008;49:1015-23.

26. Solanki A, Bansal S, Jindal S, Saxena V, Shukla US. Relationship of serum thyroid stimulating hormone with body mass index in healthy adults. Indian J EndocrinolMetab 2013;17Suppl 1:S167-9.

27. Surks MI, Ortiz E, Daniels GH, Sawin CT, Col NF, Cobin RH, et al. Subclinical thyroid disease: Scientific review and guidelines for diagnosis and management. JAMA 2004;291(2):228-38

28. Toruner F, Altinova AE, Karakoc A, Yetkin I, Ayvaz G, Cakir N, et al. Risk factors for cardiovascular disease in patients with subclinical hypothyroidism. AdvTher 2008;25:430-7.

29. Tuzcu A, Bahceci M, Gokalp D, Tuzun Y, Gunes K. Subclinical hypothyroidism may be associated with elevated high-sensitive c-reactive protein (low grade inflammation) and fasting hyperinsulinemia. Endocr J 2005;52(1):89-94

30. Udupa SV, Manjrekar PA, Udupa VA, Vivian D. Altered fructosamine and lipid fractions in subclinical hypothyroidism. J ClinDiagn Res 2013;7(1):18-22.

31. Vargas-Uricoechea H, Sierra-Torres $\mathrm{CH}$. Thyroid hormones and the heart HormMolBiolClinInvestig 2014;18(1):15-26.

32. Wang CY, Chang TC, Chen MF. Associations between subclinical thyroid disease and metabolic syndrome. Endocr J 2012;59(10):911-7.

33. Yeh ET. A new perspective on the biology of C-reactive protein. Circ Res 2005;97(7):609-11. 